\title{
Food consumption, overweight, obesity, and sociodemographic profile in a Brazilian capital: a time trend analysis between 2006 and 2018
}

\section{Consumo alimentar, excesso de peso, obesidade \\ e perfil sociodemográfico em uma capital \\ brasileira: uma análise de tendência \\ temporal entre 2006 e 2018}

\author{
Luiza Eunice Sá da SILVA 1 (ID) 0000-0003-1320-4937 \\ Thaís Cristina Marquezine CALDEIRA ${ }^{1}$ iD 0000-0002-9415-5817 \\ Rafael Moreira CLARO2 (iD) 0000-0001-9690-575X
}

\section{A B S T R A C T}

\section{Objective}

To analyze the time trend of sociodemographic characteristics and the prevalence of food consumption, overweight, and obesity variables among adults in the city of Belo Horizonte, Brazil, between 2006 and 2018.

\section{Methods}

A time series study involving data from the Sistema de Vigilância de Fatores de Risco e Proteção para Doenças Crônicas por Inquérito Telefônico (Vigitel, Surveillance System of Risk and Protective Factors for Chronic Diseases by Telephone Survey), between 2006 and 2018 in Belo Horizonte $(n=25,443)$. The annual prevalence of the population's sociodemographic characteristics (sex, age groups, and years of schooling), and risk and protective factors for chronic

\footnotetext{
1 Universidade Federal de Minas Gerais, Faculdade de Medicina, Programa de Pós-Graduação em Saúde Pública. Belo Horizonte, MG, Brasil.

2 Universidade Federal de Minas Gerais, Escola de Enfermagem, Departamento de Nutrição. Av. Prof. Alfredo Balena, n. 190, Santa Efigênia, 30130-100, Belo Horizonte, MG, Brasil. Correspondence to: RM CLARO. E-mail: <rafael.claro@gmail.com>.

Support: Coordenação de Aperfeiçoamento de Pessoal de Nivel Superior (Capes) (Código de Financiamento 001), Conselho Nacional de Desenvolvimento Científico e Tecnológico (CNPq) (Processos 309293/2016-2 e 407331/2016-6) e Fundação de Amparo à Pesquisa do Estado de Minas Gerais (Fapemig) (APQ-02329-15, 01/2015 e 535 PPM-00325-17, 02/2017).
}

How to cite this article

Silva LES, Caldeira TCM, Claro RM. Food consumption, overweight, obesity, and sociodemographic profile in a Brazilian capital: a time trend analysis between 2006 and 2018. Rev Nutr. 2021;34:e200159. https://doi.org/10.1590/1678-9865202134e200159 
diseases related to food consumption and nutritional status were estimated. Prais-Winsten regression models were used to investigate the temporal variation of each variable.

\section{Results}

From 2006 to 2018, there was a significant increase in the age and educational level of the adult population of Belo Horizonte. In the same period, the prevalence of recommended consumption of fruits and vegetables increased (from $23.0 \%$ to $29.2 \%$ ), while that of consumption of fat-rich meat and regular consumption of soft drinks decreased (respectively, from $41.9 \%$ to $38.0 \%$; from $35.3 \%$ to $15.2 \%$ ). In parallel, the prevalence of overweight and obesity increased (respectively, from $38.5 \%$ to $53.3 \%$; from $9.8 \%$ to $17.2 \%$ ).

\section{Conclusion}

An important change in the population's sociodemographic profile was noted. There are also favorable changes regarding the investigated aspects of food consumption, without these being sufficient to prevent the significant increase in the prevalence of overweight and obesity in the population.

Keywords: Food Consumption. Health surveys. Obesity. Public health.

\section{RE S U M O}

\section{Objetivo}

Este estudo objetivou analisar a tendência temporal de características sociodemográficas e da prevalência de variáveis de consumo alimentar, excesso de peso e obesidade entre adultos em Belo Horizonte entre 2006 e 2018.

\section{Métodos}

Este foi um estudo de série temporal envolvendo dados do Sistema de Vigilância de Fatores de Risco e Proteção para Doenças Crônicas por Inquérito Telefônico (Vigitel), entre 2006 e 2018, em Belo Horizonte (n=25.443). Estimou-se a prevalência anual de características sociodemográficas da população (sexo, faixa etária e anos de escolaridade) e de fatores de risco e proteção para doenças crônicas relacionados a alimentação e estado nutricional. Modelos de regressão de Prais-Winsten foram utilizados para investigar a variação temporal de cada variável.

\section{Resultados}

De 2006 a 2018, verificou-se aumento significativo da idade e da escolaridade da população adulta de Belo Horizonte. Nesse mesmo período, a prevalência de consumo recomendado de frutas e hortaliças aumentou (de $23,0 \%$ para $29,2 \%)$, enquanto aquela de consumo de carnes com excesso de gordura e de consumo regular de refrigerantes diminuiu (respectivamente, de 41,9\% para 38,0\% e de 35,3\% para 15,2\%). Em paralelo, a prevalência de excesso de peso e obesidade aumentou (respectivamente, de 38,5\% para 53,3\% e de 9,8\% para 17,2\%).

\section{Conclusão}

Importante mudança no perfil sociodemográfico da população foi constatada. Destacam-se também mudanças favoráveis quanto aos aspectos investigados do consumo alimentar, sem que estas fossem suficientes para impedir o aumento significativo na prevalência de excesso de peso e obesidade na população.

Palavras-chave: Consumo de alimentos. Inquéritos epidemiológicos. Obesidade. Saúde pública.

\section{NTRODUCTION}

In Brazil, Noncommunicable Diseases (NCD) stand as one of the main public health crises. In 2016 alone, these diseases accounted for about $74 \%$ of the causes of mortality in the country [1]. Evidence indicates that NCD-related morbidity and mortality can be reduced through public policies to control the main behavioral risk factors, such as unhealthy diets, physical inactivity, smoking, alcohol abuse, and overweight [2].

In this perspective, it is essential to identify the frequency and distribution of these factors among the population, since continuous monitoring allows the direction of appropriate public policies and actions [3]. Given this scenario, the Brazilian Ministry of Health ( $\mathrm{MH})$, through the Secretaria de Vigilância em Saúde (Health Surveillance Secretariat) and with the objective of contributing to the planning and assessment of 
actions, structured a national surveillance strategy for the main risk and protection factors for NCDs in the Brazilian population, involving surveys (such as the Pesquisa Nacional de Saúde [PNS, National Health Survey]) and their articulation with data from official Surveillance Systems (such as the Sistema de Informação sobre Mortalidade [SIM, Mortality Information System]) [3-6]. The general results of this strategy are routinely published by the $\mathrm{MH}$ for the population as a whole, without any deeper approaches to geographic regions being carried out.

It is known that most of the proposed actions for surveillance, prevention, and control, specifically on obesity and nutrition, were articulated at different levels of government, mainly with the aid of important legal frameworks supported by the Sistema Nacional de Segurança Alimentar e Nutricional (Sisan, National Food and Nutrition Security System) [7]. One of the main documents, "Estratégia Intersetorial de Prevenção e Controle da Obesidade: orientando sobre modos de vida e alimentação adequada e saudável para a população brasileira" ("Intersectoral Strategy for Prevention and Control of Obesity: advising on ways of life, and adequate and healthy nutrition for the Brazilian population"), gathers guidelines for intersectoral actions and strategies, which involve access to adequate food, as well as education and promotion of healthy lifestyles and surveillance in an integrated effort, marking its position as one of the actions to face NCD in the country [8].

It is noted, however, that the trend in the variation of the prevalence of risk and protective factors may differ between different regions of the country, as they are intensely affected by environmental conditions, such as the level of economic development and the population's educational composition. In this scenario, the realization of studies focused on specific locations is highly relevant for the establishment of more effective actions towards health promotion and disease prevention.

Belo Horizonte is the capital of the state of Minas Gerais, located in Southeastern Region of Brazil, being the sixth most populous urban concentration in the country, with approximately 2.4 million people and with a Human Development Index (HDI) of 0.810 (the fourth highest among the country's capitals) [9]. From the 1990s until the beginning of the 2000s, the city stood out as one of the scenarios for structuring programs and actions for food and nutritional health and security that would later gain national prominence, such as the Programa Academias da Cidade (City Gyms Program) - aiming at promoting healthy lifestyles - and setting up grocery stores through public-private partnerships with the obligation of selling fruits and vegetables at reduced prices [10-12].

However, little progress has been made regarding the analysis of risk and protective factors for NCD in the population of the municipality, as well as regarding to changes in their sociodemographic profile. The literature available explores specific populations, gathering information on these behaviors in users of Primary Health Care services and some sanitary districts in the capital [13-15].

In this context, monitoring the evolution of factors related to NCD in this population is important to identify relevant aspects of their health profile that will enable the adoption of more effective health promotion and disease prevention policies. The aim of this study was to analyze the time trend of sociodemographic characteristics and the prevalence of food consumption, overweight, and obesity variables among adults in the city of Belo Horizonte between 2006 and 2018.

\section{METHODS}

The study presents a time series involving secondary data from the adult population ( $\geq 18$ years old) from Belo Horizonte who participated in the Sistema de Vigilância de Fatores de Risco e Proteção para Doenças Crônicas por Inquérito Telefônico (Vigitel, Surveillance System of Risk and Protective Factors for Chronic Diseases by Telephone Survey), between 2006 and 2018 ( $n=25,443)$.

The Vigitel survey annually conducts interviews in a simple random sample of adults living in residences that have at least one landline in the 26 Brazilian capitals and the Federal District. The sampling 
used establishes about 2,000 interviews per year in each city, allowing the estimation of all the factors surveyed with a maximum error of two percentage points and a 95\% confidence interval [16].

In each year, the sampling method was initiated by drawing 5,000 landlines per city, using the landline telephone lists made available annually by the main telephone companies in Brazil [16]. From this initial draw, this sample was divided into 200 sets of landlines that reproduce the same proportion of numbers, per city, from the initial record, aiming at making calls throughout the collection period (January to December). Finally, the identification of eligible landlines was performed (being ineligible: Non-residential numbers, out-of-service numbers, and numbers that do not answer to any attempt of contact after six alternate days and times, including Saturdays, Sundays, and holidays), with an adult resident of the household answering the survey [16].

Since this is a telephone survey, a weighting strategy was applied to the data to make it representative of the entire population. A weight was assigned to each individual in order to correct the unequal probability of selection (when the residence has more than one adult or landline) and also to match the sociodemographic distribution of the population served by landlines to that of the cities' total adult population in each year of the survey (based on Census data and official projections for the population). More information on Vigitel's methodology can be found in a specific report [16].

For this research, it was used the information referred by the interviewees regarding food consumption, nutritional status, and sociodemographic characteristics. Six food consumption variables related to NCD were analyzed, three of which were admitted as protective factors - regular ( $\geq 5$ days/week) and recommended ( $\geq 5$ times/day) consumption of fruits and vegetables and regular consumption of beans ( $\geq 5$ days/week) - and three as risk factors - the consumption of fat-rich meat ( $\geq 1$ day/week) (fat-rich red meat or poultry skin), the consumption of whole milk ( $\geq 1$ day/week), and regular consumption of soft drinks ( $\geq 5$ days/week). These variables were chosen accordingly to scientific evidence that corroborate their association with NCD [17]. The regular ( $\geq 5$ days/week) or weekly ( $\geq 1$ day/week) consumption variables of the different foods were defined based on questions about the weekly frequency: "How many days a week do you usually eat [name of the food group investigated]? (1 to 2 days/week | 3 to 4 days/week | 5 to 6 days/ week | every day | almost never | never)". The recommended consumption of fruits and vegetables variable considered, in addition to the weekly frequency, the usual amount of consumption. Thus, the consumption of a fruit or a glass of fruit juice corresponded to one serving, keeping the maximum daily servings for fruits as three, and one for juices. For vegetables, a maximum consumption of four daily servings was established, classified when the individual reported consumption of raw and cooked vegetable salads at lunch and dinner [16].

The variables were defined according to the Vigitel classification, which considered models from other monitoring systems $[18,19]$, essentially for the assessment of global and national targets for facing NCD $[5,20]$. The regular and recommended consumption of fruits and vegetables, regular consumption of beans, consumption of fat-rich meat, milk with full fat content, and regular consumption of soft drinks variables were not analyzed in each years, due to changes in the methodology that made the estimate unfeasible in the period or because they were not collected in these years.

Self-reported information about the respondent's current weight and height was used to calculate the Body Mass Index (BMI). Vigitel collected this information with the questions: "Do you know your weight (even if it is an approximate value)?" and "Do you know your height?" [16]. The BMI was obtained by dividing weight, in kilograms, by the square of height, in meters. The cutoff points recommended by the World Health Organization ( $\mathrm{WHO}$ ) were used to identify overweight (BMI $\geq 25 \mathrm{~kg} / \mathrm{m}^{2}$, including overweight and obesity) and obesity $\left(\mathrm{BMI} \geq 30 \mathrm{~kg} / \mathrm{m}^{2}\right)[21]$.

The studied population was described according to the proportions for the sociodemographic characteristics collected by Vigitel: sex (male and female), age group (18 to 24, 25 to 34,35 to 44,45 to 54,55 to 64 , and $\geq 65$ years old), and years of schooling ( 0 to 8 years, 9 to 11 years, and $\geq 12$ years 
of study). The proportions of sociodemographic characteristics, food consumption, and nutritional status (independent variables) were correlated with the years analyzed (dependent variable), using Prais-Winsten linear regression models, allowing the identification of significant trends (increasing or decreasing) with the passage of time. The use of this model is indicated for time series analysis, as it allows correcting the autocorrelation of years [22]. Variations with $p<0.05$ were considered as significant. A positive variation coefficient points to an increase in the prevalence of the variable in the period; if negative, it points to a reduction; and it was considered a stationary variation when no significant differences were identified.

The Stata software, version 14.2 [23], was used to organize, process, and analyze the data. Vigitel's databases are accessible for public use on the official website of the Ministry of Health and the collection of the interviews was authorized by the Comissão Nacional de Ética em Pesquisa em Seres Humanos do Ministério da Saúde (Brazilian Ethics Committee for Research with Human Beings, Ministry of Health) (Protocol number: 65610017.1.0000.0008).

\section{R E S U L T S}

The study population was composed mostly of women, people under 45 years old, and with less than 11 years of schooling. It should be highlighted the decrease in the percentage of people aged between 18 and 24 , from $18.0 \%$ to $12.9 \%$, and an increase in people aged 45 or over, from $37.3 \%$ to $46.1 \%$. There was a reduction in the percentage of people with lower educational levels, 0 to 8 years, from $44.8 \%$ to $28.9 \%$, and an increase in the percentage of people with higher educational levels, 12 or more years of schooling, from $23.3 \%$ to $35.4 \%$ (Table 1).

There was an increase in the prevalence of recommended consumption of fruits and vegetables, from $23.0 \%$ in 2008 to $29.2 \%$ in 2018 (2.35\%/year). The consumption of fat-rich meat and regular consumption of soft drinks decreased, varying from $41.9 \%$ in 2007 to $38.0 \%$ in $2016(-1.02 \% / y e a r)$ - for fat-rich meat consumption - and 35.3\% in 2007 to $15.2 \%$ in 2018 for soft drinks (-7.85\%/year) (Table 2).

Table 1 - Distribution (\%) of the adult population ( $\geq 18$ years old) in the city of Belo Horizonte, according to sociodemographic characteristics. Sistema de Vigilância de Fatores de Risco e Proteção para Doenças Crônicas por Inquérito Telefônico'1, 2006-2018.

\begin{tabular}{|c|c|c|c|c|c|c|c|c|c|c|c|c|c|c|}
\hline Variables & $\begin{array}{c}2006 \\
n=2,013\end{array}$ & $\begin{array}{c}2007 \\
n=2,010\end{array}$ & $\begin{array}{c}2008 \\
n=2,016\end{array}$ & $\begin{array}{c}2009 \\
n=2,011\end{array}$ & $\begin{array}{c}2010 \\
n=2,007\end{array}$ & $\begin{array}{c}2011 \\
n=2,006\end{array}$ & $\begin{array}{c}2012 \\
n=1,811\end{array}$ & $\begin{array}{c}2013 \\
n=1,956\end{array}$ & $\begin{array}{c}2014 \\
n=1,519\end{array}$ & $\begin{array}{c}2015 \\
n=2,007\end{array}$ & $\begin{array}{c}2016 \\
n=2,004\end{array}$ & $\begin{array}{c}2017 \\
n=2,008\end{array}$ & $\begin{array}{c}2018 \\
n=2,072\end{array}$ & $\begin{array}{c}\text { Average } \\
\text { annual } \\
\text { variation } \\
(\%)^{*}\end{array}$ \\
\hline \multicolumn{15}{|l|}{ Sex } \\
\hline Male & 45.8 & 45.8 & 45.8 & 45.8 & 45.8 & 45.8 & 45.7 & 45.7 & 45.7 & 45.7 & 45.6 & 45.6 & 45.6 & $-0.05^{* *}$ \\
\hline Female & 54.2 & 54.2 & 54.2 & 54.2 & 54.2 & 54.2 & 54.3 & 54.3 & 54.3 & 54.3 & 54.4 & 54.4 & 54.4 & $0.04^{* *}$ \\
\hline 18 to 24 & 18.0 & 17.6 & 17.1 & 16.6 & 16.2 & 15.8 & 15.3 & 14.9 & 14.5 & 14.1 & 13.7 & 13.3 & 12.9 & $-2.76^{* *}$ \\
\hline 25 to 34 & 24.5 & 24.5 & 24.5 & 24.5 & 24.4 & 24.4 & 24.4 & 24.3 & 24.3 & 24.2 & 24.2 & 24.1 & 24.0 & $-0.16^{* *}$ \\
\hline 35 to 44 & 20.2 & 19.9 & 19.7 & 19.4 & 19.1 & 18.9 & 18.6 & 18.3 & 18.1 & 17.8 & 17.5 & 17.2 & 17.0 & $-1.44^{* *}$ \\
\hline 45 to 54 & 16.4 & 16.6 & 16.8 & 17.0 & 17.2 & 17.4 & 17.6 & 17.8 & 18.0 & 18.2 & 18.4 & 18.6 & 18.8 & $1.14^{* *}$ \\
\hline 55 to 64 & 10.6 & 10.9 & 11.1 & 11.4 & 11.7 & 11.9 & 12.2 & 12.4 & 12.7 & 13.0 & 13.3 & 13.5 & 13.8 & $2.15^{* *}$ \\
\hline 65 or more & 10.3 & 10.6 & 10.8 & 11.1 & 11.3 & 11.6 & 11.9 & 12.1 & 12.4 & 12.7 & 13.0 & 13.2 & 13.5 & $2.24^{* *}$ \\
\hline 0 to 8 & 44.8 & 43.8 & 41.1 & 40.4 & 39.7 & 37.2 & 35.4 & 35.4 & 33.9 & 33.4 & 31.0 & 30.5 & 28.9 & $-3.55^{* *}$ \\
\hline 9 to 11 & 31.9 & 33.9 & 35.5 & 35.9 & 34.8 & 37.1 & 38.0 & 36.8 & 37.8 & 37.4 & 36.3 & 36.0 & 35.7 & $0.80^{* *}$ \\
\hline 12 or more & 23.3 & 22.3 & 23.4 & 23.7 & 25.5 & 25.7 & 26.6 & 27.7 & 28.3 & 29.2 & 32.7 & 33.5 & 35.4 & $3.74^{* *}$ \\
\hline
\end{tabular}

Source: Elaborated through the Vigitel databases available on the Ministry of Health website (http://svs.aids.gov.br/download/Vigitel/).

Note: ${ }^{*}$ Corresponding to the Prais-Winsten regression coefficient of the variable over the survey year; ${ }^{* *} p<0.05$

1 Sistema de Vigilância de Fatores de Risco e Proteção para Doenças Crônicas por Inquérito Telefônico (Vigitel, Surveillance System of Risk and Protective Factors for Chronic Diseases by Telephone Survey). 
Table 2 - Evolution of the prevalence (\%) of food consumption variables in the adult population ( $\geq 18$ years old) in the city of Belo Horizonte, Brazil. Sistema de Vigilância de Fatores de Risco e Proteção para Doenças Crônicas por Inquérito Telefônico', 2006-2018.

\begin{tabular}{|c|c|c|c|c|c|c|c|c|c|c|c|c|c|c|}
\hline Variables & 2006 & 2007 & 2008 & 2009 & 2010 & 2011 & 2012 & 2013 & 2014 & 2015 & 2016 & 2017 & 2018 & $\begin{array}{c}\text { Average } \\
\text { annual } \\
\text { variation } \\
(\%)^{*}\end{array}$ \\
\hline \multicolumn{15}{|l|}{ Protective factors } \\
\hline $\begin{array}{l}\text { Regular } \\
\text { consumption } \\
\text { of fruits and } \\
\text { vegetables }\end{array}$ & - & - & 40.3 & 41.0 & 40.4 & 40.8 & 42.9 & 45.1 & 47.7 & 45.3 & 45.4 & 44.9 & 44.1 & 1.11 \\
\hline $\begin{array}{l}\text { Recommended } \\
\text { consumption } \\
\text { of fruits and } \\
\text { vegetables }\end{array}$ & - & - & 23.0 & 24.9 & 25.8 & 26.9 & 29.1 & 29.6 & 31.7 & 30.4 & 31.1 & 30.9 & 29.2 & $2.35^{* *}$ \\
\hline $\begin{array}{l}\text { Regular } \\
\text { consumption of } \\
\text { beans }\end{array}$ & - & 82.9 & 83.1 & 81.0 & 81.4 & 83.1 & 85.6 & 83.4 & 81.3 & 82.1 & 77.4 & 78.4 & - & 3.14 \\
\hline \multicolumn{15}{|l|}{ Risk factors } \\
\hline $\begin{array}{l}\text { Consumption } \\
\text { of fat-rich meat }\end{array}$ & - & 41.9 & 39.1 & 39.5 & 40.1 & 40.2 & 38.2 & 39.1 & 35.7 & 38.5 & 38.0 & - & - & $-1.02^{* *}$ \\
\hline $\begin{array}{l}\text { Consumption } \\
\text { of whole milk }\end{array}$ & - & 53.3 & 55.6 & 55.3 & 54.6 & 54.9 & 54.2 & 54.3 & 50.9 & 50.7 & 53.4 & - & - & -0.65 \\
\hline $\begin{array}{l}\text { Regular } \\
\text { consumption of } \\
\text { soft drinks }\end{array}$ & - & 35.3 & 28.0 & 28.3 & 28.2 & 27.9 & 27.3 & 22.4 & 18.2 & 18.9 & 15.2 & 14.0 & 15.2 & $-7.85^{* *}$ \\
\hline
\end{tabular}

Source: Elaborated through the Vigitel databases available on the Ministry of Health website (http://svs.aids.gov.br/download/Vigitel/).

Note: ${ }^{*}$ Corresponding to the Prais-Winsten regression coefficient of the variable over the survey year; ${ }^{* *} p<0.05$.

${ }^{1}$ Sistema de Vigilância de Fatores de Risco e Proteção para Doenças Crônicas por Inquérito Telefônico (Vigitel, Surveillance System of Risk and Protective Factors for Chronic Diseases by Telephone Survey).

Despite the positive results regarding food consumption, more than half of the population was overweight in 2018, with an average increase of 2.35\%/year (ranging from 38.50\% in 2006 to $53.30 \%$ in 2018). The prevalence of overweight, in all years analyzed, was higher among men, however, with an annual variation almost twice as high among women (3.13\%/year), when compared to men (1.61\%/year). At the same time, there was an increase in the prevalence of obesity from $9.80 \%$ in 2006 to $17.20 \%$ in 2018 , with a change of $4.21 \% / y e a r$. Regarding obesity, women presented, in most years, a higher prevalence than men did; however, men presented a greater annual variation (4.58\%/year) when compared to women (4.03\%/year) (Table 3).

Table 3 - Evolution of the prevalence (\%) of overweight and obesity in the adult population ( $\geq 18$ years old) in the city of Belo Horizonte, according to sex. Sistema de Vigilância de Fatores de Risco e Proteção para Doenças Crônicas por Inquérito Telefônico', 2006 -2018.

\begin{tabular}{lcccccccccccccc}
\hline Variables & 2006 & 2007 & 2008 & 2009 & 2010 & 2011 & 2012 & 2013 & 2014 & 2015 & 2016 & $\begin{array}{c}\text { Average } \\
\text { annual } \\
\text { variation } \\
(\%)^{*}\end{array}$ \\
\hline Overweight & 38.5 & 41.2 & 42.7 & 44.4 & 44.1 & 45.6 & 48.1 & 47.3 & 48.5 & 50.4 & 49.6 & 51.1 & 53.3 & $2.35^{* *}$ \\
$\quad$ Male & 44.8 & 47.2 & 46.6 & 48.4 & 48.8 & 49.9 & 52.0 & 48.4 & 49.7 & 55.4 & 52.7 & 53.1 & 56.6 & $1.61^{* *}$ \\
$\quad$ Female & 33.2 & 36.1 & 39.4 & 41.0 & 40.1 & 42.1 & 44.7 & 46.3 & 47.5 & 46.2 & 46.9 & 49.5 & 50.5 & $3.13^{* *}$ \\
Obesity & 9.8 & 11.7 & 12.1 & 12.8 & 12.8 & 14.1 & 14.5 & 14.6 & 16.5 & 17.4 & 16.6 & 16.4 & 17.2 & $4.21^{* *}$ \\
$\quad$ Male & 9.7 & 10.7 & 11.0 & 10.5 & 12.0 & 12.9 & 13.3 & 13.7 & 14.9 & 15.7 & 14.9 & 17.2 & 15.8 & $4.58^{* *}$ \\
Female & 9.9 & 12.5 & 13.0 & 14.7 & 13.6 & 15.1 & 15.5 & 15.4 & 17.9 & 18.8 & 18.0 & 15.8 & 18.5 & $4.03^{* *}$ \\
\hline
\end{tabular}

Source: Elaborated through the Vigitel databases available on the Ministry of Health website (http://svs.aids.gov.br/download/Vigitel/).

Note: ${ }^{*}$ Corresponding to the Prais-Winsten regression coefficient of the variable over the survey year; ${ }^{* *} p<0.05$.

1 Sistema de Vigilância de Fatores de Risco e Proteção para Doenças Crônicas por Inquérito Telefônico (Vigitel, Surveillance System of Risk and Protective Factors for Chronic Diseases by Telephone Survey). 


\section{DISCUSSION}

For the first time, the evolution of the prevalence of food consumption variables and overweight and obesity in the population of Belo Horizonte was analyzed. Throughout the study period, the prevalence of both regular and recommended consumption of fruits and vegetables was higher than those observed in the set of Brazilian capitals $[16,24]$. In fact, the percentage of adults in Belo Horizonte who consumed fruits and vegetables as recommended in 2018 (29.2\%) already reached a percentage higher than the goal proposed for Brazil until 2022, in the Plano de Ações Estratégicas para o Enfrentamento das Doenças Crônicas não Transmissíveis (Strategic Action Plan to Tackle Noncommunicable Diseases), of 24.3\% [5].

Further details that indicate the increase in the proportion of overweight and obese people is also available for the total of the country's capitals [16]. In 2006, $42.6 \%$ of adults in Brazilian capitals were overweight, reaching 55.7\% in 2018, and those with obesity went from 11.8\% in 2006 to 19.8\% in 2018 [16]. In such a way, the proportion of overweight and obesity observed in Belo Horizonte only positions the city as the one with the $19^{\text {th }}$ highest frequency of overweight and the $22^{\text {nd }}$ highest prevalence of obesity among the country's 26 capitals and the Distrito Federal in 2018, with frequencies of overweight and obesity, respectively, 7.4 and 5.8 percentage points lower than the cities with the highest values observed: Cuiabá (60.7\% overweight) and Manaus (23.0\% with obesity) [16].

The increase in the prevalence of overweight and obesity follows an alarming trend not only in high-income countries, but also in those of low- and middle-income countries $[25,26]$. The prevalence of obesity worldwide increased from $3 \%$ in 1975 to $11 \%$ in 2016, for men, and from $6 \%$ to $15 \%$, for women [25]. Differences in prevalence between men and women are also found in the literature and have sociocultural, economic, behavioral, and biological reasons [25-27].

Regarding the increase in the recommended consumption of fruits and vegetables and reduction in the consumption of fat-rich meat or soft drinks, similar results can be found in other studies $[24,28,29]$. Although the objective of the present study is not to investigate the causes of the observed trends, the implementation of programs and public policies in line with national plans to fight NCD and to prevent and control obesity may contribute to the trend towards improvement in the food consumption of the population of Belo Horizonte $[5,8]$. Nutrition actions have been strengthened in the last decade, with the inclusion of Nutritionists in the Primary Health Care teams [30]. A series of actions and programs developed in the municipality (some for more than a decade) act both in increasing the supply of food, such as fruits and vegetables - the Direto da Roça, Feiras Livres, Hortas urbanas, Programa de Sacolões ABasteCer, and the Restaurantes Populares (Straight from the Country, Street fairs, Urban gardens, and the ABasteCer Program government-backed grocery stores, and Popular Restaurants) - as well as representing important spaces for the promotion of healthy eating [12]. Since these programs act on price reduction and expand access to these foods, these strategies can favor the consumption of healthy foods [31]. The maintenance of these actions, in partnership with a robust set of food and nutrition education practices - carried out especially with schoolchildren and the population with greater social vulnerability - has possibly been contributing to a favorable evolution of the nutritional pattern in the municipality [32].

It is noteworthy, however, that only about a third of the adults in Belo Horizonte reported consuming fruits and vegetables adequately in 2018, and more than $15 \%$ of adults consumed soft drinks regularly. This means that the trends observed here are not yet to be celebrated. Furthermore, considering the increasing participation of ultra-processed foods in the Brazilian diet, such as snacks, drinks, and ready meals, future studies for specific research in this city should be prioritized, since the consumption of these foods is associated with weight gain, as a result of their high energy content and high amounts of sodium, free sugars, and fats [33]. A set of intersectoral actions to regulate the environment, such as the taxation 
of ultra-processed foods, proper food labeling bringing clear information on the content of ingredients, in addition to restricting the entry of these foods into the school environment and to the high exposure to advertising, are currently the most favorable and effective proposals for tackling obesity [34-36]. In Brazil, some of the discussions on these actions were initiated by the Brazilian government, but are taking slow steps. Nevertheless, they contrast with the scientific evidence, even those that have already had some progress, due to the strong interest of the food industry in the decision-making process.

Still, a greater effectiveness of the actions presented is conditioned to the expansion of the program's coverage. Some studies have pointed out that establishments offering healthy food are scarce in areas of greater social vulnerability in Belo Horizonte $[37,38]$. The Programa Academias da Saúde (Health Gyms Program), designed mainly to change the levels of physical activity for the entire population, do not reach all population strata [39]. Thus, the expansion of programs must keep in mind, for example, that the annual variation in obesity presented here (4.21\%/year) translates into about 30 thousand new cases each year in the city (data not shown).

Finally, the increase in the number of a population's NCD may reflect changes in the sociodemographic profile as well as changes in behaviors [40]. The analysis carried out in the present study showed an increase in the population's age and educational level, which is possibly related to the changes observed regarding food consumption and nutritional status. Many studies have already proposed to investigate these associations, finding a direct relationship between healthy diet, as well as obesity, and age and educational level $[27,41,42]$. These sociodemographic characteristics (age and educational level), as well as other genetic and socio-environmental factors (such as sex, race/ethnicity, socioeconomic and psychosocial position, and the social and structural environment) are defined as distal health determinants in the multi-causal context associated with weight gain, and, when compared to proximal determinants (diet and physical activity), they can directly interfere in the occurrence of this outcome [43]. Although it was not analyzed based on the available data, it is suggested for the next studies that this multi-causal context be also investigated.

Understanding the changes experienced, the Brazilian government has made many efforts in recent decades to overcome the challenges of the transition process, especially in nutritional matters [44]. Conversely, in the last 5 years, the country has experienced a serious economic and political crisis, marked by the disruption of important social and health policies and the postponement of important discussions for tackling obesity. In this scenario, the continuous monitoring of factors related to NCD should be encouraged, with the potential to portray the results of these changes and support decision-making to face these conditions in the country.

It is necessary, however, to acknowledge some limitations when analyzing the results of this study. It is important to consider that the information presented in this study is self-reported, which could undermine its accuracy. Despite this, information based on the condition mentioned by the interviewees is encouraged for the investigation and monitoring of risk factors between countries and is widely used by other internationally consolidated surveys [18-19]. In addition, most of the variables used in this study, had their validity tested, confirming the accuracy of the estimates $[45,46]$. Finally, even if Vigitel is restricted to interviewing households with a landline, the use of statistical adjustment, using weighting factors, aims to match the estimated sociodemographic percentage for the population of adults living in households with a landline in each location to the total sociodemographic percentage of the adult population in the same location [16].

\section{CONCLUSION}

An important change in the socio-demographic profile of the adult population of Belo Horizonte was observed between the years 2006 and 2018. It is noteworthy that there have been favorable changes in the 
investigated aspects of food consumption; despite that, these changes have not yet been enough to prevent an increase in the overweight and obesity indice. In this sense, new studies should be carried out seeking possible explanations for the increase in the frequency of these conditions, in addition to the continuation of health promotion actions, which have been carried out in the city, and the expansion of public policies that promote healthy environments.

\section{ACKNOWLEDGMENTS}

The authors would like to thank the Coordenação de Aperfeiçoamento de Pessoal de Nível Superior (Capes), for funding the scholarship, and the Brazilian Ministry of Health, for their support.

\section{CONTRIBUTORS}

LES SILVA and RM CLARO contributed to the conception, planning, analysis and interpretation of data, and preparation of the article. TCM CALDEIRA contributed to the conception, planning, and critical review of the content of the article. All authors approved the final version to be published.

\section{REFERE N CES}

1. World Health Organization. Noncomummunicable Diseases (NCD) Country Profiles 2018. Geneva: Organization; 2018 [cited 2020 Sept 10]. Available from: https://apps.who.int/iris/handle/10665/274512

2. Isaranuwatchai $W$, Teerawattananon $Y$, Archer RA, Luz A, Sharma $M$, Rattanavipapong $W$, et al. Prevention of non-communicable disease: best buys, wasted buys, and contestable buys. Bmj. 2020;368:m141. https://doi. org/10.1136/bmj.m141

3. Malta DC, Silva MMA, Moura L, Morais NOL. A implantação do Sistema de Vigilância de Doenças Crônicas Não Transmissíveis no Brasil, 2003 a 2015: alcances e desafios. Rev Bras Epidemiol. 2017;20(4):661-75. https://doi. org/10.1590/1980-5497201700040009

4. Ministério da Saúde (Brasil). A vigilância, o controle e a prevenção das doenças crônicas não-transmissíveis: DCNT no contexto do Sistema Único de Saúde brasileiro. Brasília: Organização Pan-Americana da Saúde; 2005.

5. Ministério da Saúde (Brasil). Plano de Ações Estratégicas para o Enfrentamento das Doenças Crônicas Não Transmissíveis (DCNT) no Brasil 2011-2022. Brasília: Ministério; 2011.

6. Malta DC, Oliveira TP, Santos MAS, Andrade SSCA, Silva MMA. Avanços do Plano de Ações Estratégicas para o Enfrentamento das Doenças Crônicas não Transmissíveis no Brasil, 2011-2015. Epidemiol Serv Saúde. 2016;25(2):373-90. https://doi.org/10.5123/s1679-49742016000200016

7. Câmara Interministerial de Segurança Alimentar e Nutricional (Brasil). II Plano Nacional de Segurança Alimentar e Nutricional: PLANSAN 2016-2019. Brasília: Câmara; 2018 [citado 18 jul 2019]. Disponível em: http://www.mds.gov. br/webarquivos/arquivo/seguranca_alimentar/caisan/Publicacao/Caisan_Nacional/BalancoPLANSAN2016_2019.pdf

8. Câmara Interministerial de Segurança Alimentar e Nutricional. Estratégia Intersetorial de Prevenção e Controle da Obesidade: recomendações para estados e municípios. Brasília: Câmara; 2014. Disponível em: http://www.mds.gov. br/webarquivos/publicacao/seguranca_alimentar/estrategia_prevencao_obesidade.pdf

9. Instituto Brasileiro de Geografia e Estatística. Brasil em síntese: Minas Gerais, Belo Horizonte: panorama. Rio de Janeiro: Instituto; 2017 [citado 18 Jul. 2019]. Disponível em: https://cidades.ibge.gov.br/brasil/mg/belo-horizonte/ panorama.

10. Fernandes AP, Andrade ACS, Costa DAS, Dias MAS, Malta DC, Caiaffa WT. Programa Academias da Saúde e a promoção da atividade física na cidade: a experiência de Belo Horizonte, MG, Brasil. Ciênc Saúde Coletiva. 2017;22(12):3903-14. https://doi.org/10.1590/1413-812320172212.25282017

11. Sá GBAR, Dornelles GC, Cruz KG, Amorim RCA, Andrade SSCA, Oliveira TP, et al. O Programa Academia da Saúde como estratégia de promoção da saúde e modos de vida saudáveis: cenário nacional de implementação. Ciênc Saúde Coletiva. 2016;21(6):1849-60. https://doi.org/10.1590/1413-81232015216.09562016 
12. Lopes ACS, Menezes MC, Araujo ML. O ambiente alimentar e o acesso a frutas e hortaliças: Uma metrópole em perspectiva. Saúde Soc. 2017;26(3):764-73. https://doi.org/10.1590/s0104-12902017168867

13. Oliveira MS, Lacerda LNL, Santos LC, Lopes ACS, Sette Câmara AMC, Menzel HJK, et al. Consumo de frutas e hortaliças e as condições de saúde de homens e mulheres atendidos na atenção primária à saúde. Ciênc Saúde Coletiva. 2015;20(8):2312-22. https://doi.org/10.1590/1413-81232015208.18272014

14. Bedeschi LB, Lopes ACS, Santos LC. Stages of change and factors associated with misperceived eating behavior in obese individuals. Rev Nutr. 2016;29(1):33-42. https://doi.org/10.1590/1678-98652016000100004

15. Andrade RG, Chaves OC, Costa DAS, Andrade ACS, Bispo S, Felicissimo MF, et al. Excesso de peso em homens e mulheres residentes em área urbana: fatores individuais e contexto socioeconômico. Cad Saude Publica. 2015;31:S148-58. https://doi.org/10.1590/0102-311X00102714

16. Ministério da Saúde (Brasil). Vigitel Brasil 2018: vigilância de fatores de risco e proteção para doenças crônicas por inquérito telefônico: estimativas sobre frequência e distribuição sociodemográfica de fatores de risco e proteção para doenças crônicas nas capitais dos 26 estados brasileiros e no Distrito Federal em 2018. Brasília: Ministério; 2019.

17. World Health Organization. Diet, nutrition and the prevention of chronic diseases: report of a Joint WHO/FAO Expert Consultation. Geneva: Organization; 2003 [cited 2019 July18]. Available from: https://apps.who.int/iris/bitstream/ handle/10665/42665/WHO_TRS_916.pdf?sequence=1

18. Riley L, Guthold R, Cowan M, Savin S, Bhatti L, Armstrong T, et al. The World Health Organization STEPwise approach to noncommunicable disease risk-factor surveillance: methods, challenges, and opportunities. Am J Public Health. 2016;106(1):74-8. https://doi.org/10.2105/AJPH.2015.302962

19. Pickens CM, Pierannunzi C, Garvin W, Town M. Surveillance for certain health behaviors and conditions among states and selected local areas: behavioral risk factor surveillance system, United States, 2015. Morb Mortal Wkly Rep Surveill Summ. 2018;67(9):1-90. https://doi.org/10.15585/mmwr.ss6709a1

20. World Health Organization. Global action plan for the prevention and control of noncommunicable diseases 2013-2020. Geneva: Organization; 2013 [cited 2019 July 18]. Available from: https://apps.who.int/iris/bitstream/ handle/10665/94384/9789241506236_eng.pdf?sequence=1

21. World Health Organization. Obesity: preventing and managing the global epidemic: report of a WHO consultation. Geneva: Organization; 2000 [cited 2019 July 18]. Available from: https://www.who.int/nutrition/publications/ obesity/WHO_TRS_894/en/

22. Antunes JLF, Cardoso MRA. Uso da análise de séries temporais em estudos epidemiológicos. Epidemiol Serv Saude 2015;24(3):565-76. https://doi.org/10.5123/\$1679-49742015000300024

23. Stata Corporation. Stata Statistical Software. Release 14. [software] College Station: Stata Corporation LP; 2015.

24. Silva LES, Claro RM. Tendências temporais do consumo de frutas e hortaliças entre adultos nas capitais brasileiras e Distrito Federal, 2008-2016. Cad Saúde Pública. 2019;35(5):2008-16. https://doi.org/10.1590/0102-311x00023618

25. NCD Risk Factor Collaboration (NCD-RisC). Trends in adult body-mass index in 200 countries from 1975 to 2014: a pooled analysis of 1698 population-based measurement studies with 19.2 million participants. Lancet. 2016;387(10026):1377-96. https://doi.org/10.1016/S0140-6736(16)30054-X

26. Jaacks LM, Vandevijvere $S$, Pan A, McGowan CJ, Wallace C, Imamura F, et al. The obesity transition: stages of the global epidemic. Lancet Diabetes Endocrinol. 2019;7(3):231-40. https://doi.org/10.1016/\$2213-8587(19)30026-9

27. Ameye H, Swinnen J. Obesity, income and gender: the changing global relationship. Glob Food Sec. 2019;23:267-81. https://doi.org/10.1016/j.gfs.2019.09003

28. Longo-Silva G, Silveira JAC, Menezes RCE, Marinho PM, Epifânio SBO, Brebal KMM, et al. Tendência temporal e fatores associados ao consumo de carnes gordurosas na população brasileira entre de 2007 a 2014. Ciênc Saúde Coletiva. 2019;24(3):1175-88. https://doi.org/10.1590/1413-81232018243.0819201

29. Figueiredo N, Maia EG, Silva LES, Granado FS, Claro RM. Trends in sweetened beverages consumption among adults in the Brazilian capitals, 2007-2016. Public Health Nutr. 2018;21(18):3307-3317. http://dx.doi.org/10.1017/ S1368980018002161

30. Bortolini GA, Oliveira TFV, Silva SA, Santin RDC, Medeiros OL, Spaniol AM, et al. Ações de alimentação e nutrição na atenção primária à saúde no Brasil. Rev Panam Salud Publica. 2020;44:e39. https://doi.org/10.26633/RPSP.2020.39

31. Pessoa MC, Mendes LL, Gomes CS, Martins PA, Velasquez-Melendez G. Food environment and fruit and vegetable intake in a urban population: a multilevel analysis. Bmc Public Health. 2015;15:1012. https://doi.org/10.1186/ s12889-015-2277-1 
32. Carmo AS, Sousa TM, Silva CM, Silva AR, Silva AC, Lacerda AT, et al. Nutritional intervention based on ludic activities: effect on eating habits and nutritional status of Brazilian schoolchildren. J Food Nutr Res. 2018;6(5):302-05. https:// doi.org/10.12691/jfnr-6-5-4

33. Mendonça RD, Pimenta AM, Gea A, Fuente-Arrillaga C, Martinez-Gonzalez MA, Lopes ACS, et al. Ultraprocessed food consumption and risk of overweight and obesity: the University of Navarra follow-up (SUN) cohort study. Am J Clin Nutr. 2016;104(5):1433-40. https://doi.org/10.3945/ajcn.116.135004

34. Passos CM, Maia EG, Levy RB, Martins APB, Claro RM. Association between the price of ultra-processed foods and obesity in Brazil. Nutr Metab Cardiovasc Dis. 2020;30(4):589-98. https://doi.org/10.1016/j.numecd.2019.12.011

35. Khandpur N, Mais LA, Sato PM, Martins APB, Spinillo CG, Rojas CFU, et al. Choosing a front-of-package warning label for Brazil: a randomized, controlled comparison of three different label designs. Food Res Int. 2019;121:854-61. https://doi.org/10.1016/j.foodres.2019.01.008

36. Guimarães JS, Mais LA, Leite FHM, Horta PM, Santana MO, Martins APB, Claro RM. Ultra-processed food and beverage advertising on Brazilian television by International Network for Food and Obesity/Non-Communicable Diseases Research, Monitoring and Action Support benchmark. Public Health Nutr. 2020;23(15):2657-62. https:// doi.org/10.1017/S1368980020000518

37. Menezes MC, Costa BV, Oliveira CD, Lopes AC. Local food environment and fruit and vegetable consumption: an ecological study. Prev Med Rep. 2016;5:13-20. https://doi.org/10.1016/j.pmedr.2016.10.015

38. Pimentel T. Pesquisa da UFMG aponta que periferia de BH tem 'desertos alimentares', áreas onde não há oferta de comida saudável. G1. 24 nov 2019 [citado 8 nov. 2019]. Disponível em: https://g1 .globo.com/mg/minas-gerais/ noticia/2019/11/24/pesquisa-da-ufmg-aponta-que-periferia-de-bh-tem-desertos-alimentares-areas-onde-nao-haoferta-de-comida-saudavel.ghtml

39. Fernandes AP, Andrade ACS, Ramos CGC, Friche AAL, Dias MAS, Xavier CC, et al. Leisure-time physical activity in the vicinity of Academias da Cidade Program in Belo Horizonte, Minas Gerais State, Brazil: the impact of a health promotion program on the community. Cad Saúde Pública. 2015;31(Suppl1):195-207. https://doi.org/10.1590/0102$311 \times 00104514$

40. Souza MFM, Malta DC, França EB, Barreto ML. Transição da saúde e da doença no Brasil e nas Unidades Federadas durante os 30 anos do Sistema Único de Saúde. Ciênc Saúde Coletiva. 2018;23(6):1737-50. https://doi. org/10.1590/1413-81232018236.04822018

41. Enes CC, Nucci LB. Gender and schooling inequalities in risk and protective factors for chronic diseases among Brazilian adults. J Public Health. 2018;40(3):e211-8. https://doi.org/10.1093/pubmed/fdx183

42. Ferreira APS, Szwarcwald CL, Damacena GN. Prevalência e fatores associados da obesidade na população brasileira: estudo com dados aferidos da Pesquisa Nacional de Saúde, 2013. Rev Bras. Epidemiol. 2019;22:e190024. https:// doi.org/10.1590/1980-549720190024

43. Bennett GG, Wolin KY, Duncan DT. Social Determinants of Obesity. In: Hu, FB. Obesity Epidemiology. New York: Oxforxd, 2008.

44. Jaime PC, Delmuè DCC, Campello T, Oliveira e Silva D, Santos LMP. Um olhar sobre a agenda de alimentação e nutrição nos trinta anos do Sistema Único de Saúde. Ciênc Saúde Coletiva. 2018;3(6):1829-36. https://doi. org/10.1590/1413-81232018236.05392018

45. Mendes LL, Campos SF, Malta DC, Bernal RTI, Sá NNB, Velásquez-Meléndez G. Validade e reprodutibilidade de marcadores do consumo de alimentos e bebidas de um inquérito telefônico realizado na cidade de Belo Horizonte (MG), Brasil. Rev Bras Epidemiol. 2011;14(Suppl1):80-9. https://doi.org/10.1590/S1415-790X2011000500009

46. Moreira NF, Luz VG, Moreira CC, Pereira RA, Sichieri R, Ferreira MG, et al. Self-reported weight and height are valid measures to determine weight status: results from the Brazilian National Health Survey (PNS 2013). Cad Saúde Pública. 2018;34(5):e00063917. https://doi.org/10.1590/0102-311X00063917 